\title{
Specific binding of aspartic protease and enterocytes promotes Trichinella spiralis invasion of murine intestinal epithelium cells
}

\author{
Xu, J. ${ }^{1}$, Xu, Y.X.Y. ${ }^{2}$, Yue, W.W. ${ }^{1}$, Hao, H.N. ${ }^{1}$, Liu, R.D. ${ }^{1}$, Long, S.R. ${ }^{1}$, Wang, Z.Q. ${ }^{1 *}$, Cui, J. ${ }^{1 *}$ \\ ${ }^{1}$ Department of Parasitology, Medical College, Zhengzhou University, 40 Daxue Road, Zhengzhou 450052, People's Republic of China \\ ${ }^{2}$ School of Life Science, Zhengzhou University, 40 Daxue Road, Zhengzhou 450052, People's Republic of China \\ *Corresponding authors: wangzq@zzu.edu.cn; wangzq2015@126.com; Jing Cui; cuij@zzu.edu.cn
}

\section{ARTICLE HISTORY}

Received: 20 September 2020 Revised: 6 January 2021

Accepted: 9 January 2021

Published: 25 March 2021

\begin{abstract}
Trichinella spiralis is an important foodborne zoonotic parasite and it is necessary to develop vaccine to prevent $T$. spiralis infection in food animals. $T$. spiralis aspartic protease-2 (TSASP2) has been demonstrated to play a crucial role in larval invasion of intestinal epithelium cells (IECs). The purpose of this study was to assess the interaction between TsASP2 and IECs and to investigate the immune protection elicited by vaccination with rTsASP2. The results showed that the enzymatic activity of native aspartic protease was detected in crude proteins of all $T$. spiralis development stages other than NBL stage, the highest activity was observed in the IIL stage. The results of Western blot showed that TSASP2 protein was expressed at $\mathrm{ML}$, IIL and AW but not NBL, and the TsASP2 expression level at IIL stage was significantly higher than those of other three worm stages $(P<0.05)$. The specific binding between rTsASP2 and IECs was observed by immunofluorescence test (IFT) and confocal microscopy, and the binding site was localized at the IEC membrane and this binding ability was inhibited by aspartic protease specific inhibitor pepstain $A$. The results of ELISA showed that the binding ability was protein dose-dependent. Vaccination with rTsASP2 triggered a mixed Th1/Th2 humoral and mucosal immune responses, as demonstrated by the elevation levels of Th1/Th2 cytokines (IFN- $\gamma$ and IL-4) secreted by the spleen and mesenteric lymph nodes (MLNs) of immunized mice. The mice vaccinated with rTsASP2 exhibited a $54.17 \%$ reduction in enteral adult worms and a $54.58 \%$ reduction in muscle larvae after $T$. spiralis challenge. The results demonstrated that TSASP2 might be a potential molecular target for anti-Trichinella vaccines.
\end{abstract}

Keywords: Trichinella spiralis; aspartic protease; interaction; invasion; intestinal epithelium.

\section{INTRODUCTION}

Trichinella spiralis is an important foodborne pathogen that has been found to infect many kinds of mammalian species (Pozio, 2007). Human Trichinella infection is mainly caused from ingestion of raw or poorly cooked meat containing the infective larvae of Trichinella (Cui et al., 2013a). Outbreaks of trichinellosis have been reported in many countries, especially in developing countries. From 2004 to 2009, 15 trichinellosis outbreaks were reported in mainland China (Cui et al., 2011). The main infection source of trichinellosis is domestic pigs (Jiang et al., 2016; Rostami et al., 2017). This disease has become an important public health problem and gained an increasing attention worldwide. Therefore, it is necessary to develop the vaccines to block Trichinella infection transmission in food animals (Bai et al., 2017; Qi et al., 2018).

After the infected muscle tissue is ingested and digested by the digestive enzymes, the muscle larvae (ML) are released and then activated into intestine infective larvae (IIL) by exposure to intestinal contents or bile (Ren et al., 2013). The IIL penetrate into the enteric epithelium and grow to adult worms (AWs). The IIL invasion of intestinal epithelium cells (IECS) is crucial for the establishment of Trichinella infection (Liu et al., 2013). Intestinal epithelium is not only the first host's native innate defense barrier but also the principal interaction location between $T$. spiralis and the host (Long et al., 2015; Wang et al., 2017). Therefore, analysis of the interaction between $T$. spiralis proteins and the IECs is helpful to elucidate the mechanism of the Trichinella invasion of intestinal epithelium (Han et al., 2020; $\mathrm{Hu}$ et al., 2020b).

Trichinella spiralis excretory/secretory (ES) proteins play an essential role in parasite invasion and regulating host immune responses (Bolas-Fernandez et al., 2006; Bien et al., 2012). In our previous studies, a T. spiralis aspartic protease2 (TsASP2; GenBank: 339237490) was identified from ES proteins of ML and IIL. Recombinant TSASP2 (rTsASP2) was 
expressed and purified and it possessed the aspartic protease activity, cleaved several host proteins, facilitated T. spiralis invasion of murine IECs (Xu et al., 2020a). The purpose of this study was to assess the interaction between TsASP2 and IECS and to investigate the immune protection elicited by vaccination with rTsASP2.

\section{MATERIALS AND METHODS}

\section{Parasites, experimental animals}

T. spiralis strain (ISS534) utilized in this experiment was collected from domestic pigs in central China (Wang et al., 2012). Female BALB/c mice aged 5 weeks old were purchased from the Experimental Animal Center of Henan Province. All animal experimental procedures were approved by the Life Science Ethics Committee of Zhengzhou University (No. SCXK 2017-0001)

\section{Preparation of worm crude protein and rTSASP2 protein}

T. spiralis $\mathrm{ML}$ from infected mice were obtained using artificial digestion $(1 \%$ pepsin and $0.75 \% \mathrm{HCl}$ ) at 35 days post infection (dpi) (Jiang et al., 2012). The IIL were isolated from the infected mouse intestines at 6,12 and 24 hours post infection (hpi) and the AWs were obtained from mouse intestines at 36, 48, $60 \mathrm{hpi}$ and $3 \mathrm{dpi}$, and $6 \mathrm{dpi}$ (Liu et al., 2015c; Sun et al., 2015). The AW were cultured in DMEM for $24 \mathrm{~h}$ at $37^{\circ} \mathrm{C}$ and the NBL were harvested (Li et al., 2015; Wu et al., 2016). T. spiralis worms were homogenized with tissue grinder and ultrasonication, then the supernatant containing worm crude proteins was collected after centrifugation (Yang et al., 2015). The concentration of crude proteins was measured by the Bradford method. The rTSASP2 protein was prepared in our laboratory (Xu et al., 2020a). The Escherichia coli BL21 (DE3) containing the recombinant plasmid pMAL-c2x/ TsASP2 was induced with $0.1 \mathrm{mM}$ IPTG at $16^{\circ} \mathrm{C}$ for $20 \mathrm{~h}$, the rTsASP2 was purified with an Amylose Prepacked Column (NEB, China) (Cui et al., 2015b; $\mathrm{Xu}$ et al., 2018). The anti-rTsASP2 serum was prepared as described (Long et al., 2014; Sun et al., 2018b).

Analysis of aspartic protease activity in different stages of $T$. spiralis The fluorescent substrate MCA-Gly-Lys-Pro-IleLeu-Phe-PheArg-Leu-Lys (DNP)-D-Arg- amide (synthesized by Sangon Biotech Co., Shanghai, China) was used to assess the aspartic protease enzymatic activity of $T$. spiralis soluble crude proteins. Total reaction volume was $100 \mu \mathrm{l}$, including $50 \mu \mathrm{g} / \mathrm{ml}$ crude proteins and $5 \mu \mathrm{M}$ fluorescent substrate. After mixing the crude proteins and substrate for $30 \mathrm{~min}$, the reaction termination fluid (35\% methyl alcohol, 30\% ethyl alcohol, $35 \% \mathrm{ddH}_{2} \mathrm{O}$ ) was added, and the fluorescent intensity was continuously detected with spectrophotofluorometry (Synergy H1, BioTek, USA) using excitation wavelength 320 $\mathrm{nm}$ and emission wavelength $390 \mathrm{~nm}$, respectively (MantillaOlea et al., 2018).

\section{RT-PCR and Western blotting analysis of TSASP2 expression in} various $T$. spiralis phases

Total RNAs from ML, IIL, 3 day AW, 6 day AW and NBL were extracted using Trizol reagent (Invitrogen, USA). RT-PCR was performed to ascertain TSASP2 gene transcription in different T. spiralis stages as previously reported (Zhang et al., 2013). A control gene GAPDH from $T$. spiralis (GenBank: AF452239) was also amplified (Wang et al., 2013a).

The crude proteins of $T$. spiralis at various stages (ML, IILs, AW at $3 \mathrm{dpi}, A W$ at $6 \mathrm{dpi}$ and NBL) were separated by SDS-PAGE (Wang et al., 2013b), and these proteins were transferred onto the polyvinylidene difluoride (PVDF) membrane. The membrane was first incubated with $5 \%$ skimmed milk in Tris-buffered saline- 0.5\% Tween-20 (TBST) at $37^{\circ} \mathrm{C}$ for $2 \mathrm{~h}$, and then reacted with anti-rTsASP2 serum (1:100 dilution) at $37^{\circ} \mathrm{C}$ for $1 \mathrm{~h}$. After washing with TBST 3 times, the membrane was incubated with HRP-conjugated anti-mouse IgG (Sigma-Aldrich, USA) at $37^{\circ} \mathrm{C}$ for $1 \mathrm{~h}$. After washing again, the membrane was visualized using an enhanced chemiluminescent Kit (Beyotime Biotech, China) (Liu et al., 2014; Wang et al., 2014; Zhang et al., 2016). The mouse anti-GAPDH antibody was used as an internal control after the membrane was washed with the stripping buffer (Beyotime Biotech, China) (Liu et al., 2016; Yang et al., 2019a) .

\section{Immunofluorescence test (IFT)}

The location of TsASP2 at T. spiralis worms was observed by IFT as previously reported (Liu et al., 2018; Cui et al., 2019). T. spiralis worms (ML, IIL, AW at $3 \mathrm{dpi}$ and $\mathrm{NBL}$ ) and intestine isolated from infected mice at $6 \mathrm{hpi}$ and $3 \mathrm{dpi}$ were embedded in paraffin and sliced into $2 \mu \mathrm{m}$-thick sections. The sections were blocked with $5 \%$ normal goat serum at $37^{\circ} \mathrm{C}$ for $30 \mathrm{~min}$ and then probed by anti-rTsASP 2 serum. The sections were also incubated with infection serum or normal serum as positive or negative control. The FITC-conjugated anti-mouse IgG (1:100; Santa Cruz, USA) was used to stain the section, and the results were observed under fluorescent microscopy (Olympus, Japan) (Li et al., 2018; Song et al., 2018b)

ELISA analysis of specific binding between TSASP2 and IEC protein The IECs were isolated from normal mouse intestine in our laboratory (Ren et al., 2011). The binding between TsASP2 and IECs was measured by ELISA (Sun et al., 2018a; Guo et al., 2020). Briefly, the ELISA plate was coated with various concentrations of IEC proteins overnight at $4^{\circ} \mathrm{C}$. After blocking with $5 \%$ skimmed milk in PBST, the ELISA plate was incubated with different concentrations of rTsASP2 at $37^{\circ} \mathrm{C}$ for $2 \mathrm{~h}$. AntirTsASP2 serum and normal serum (1:100) were added in the plate at $37^{\circ} \mathrm{C}$ for $1 \mathrm{~h}$ and then HRP labelled anti-mouse IgG was added as the secondary antibodies. The result was colored with 3, 3', 5, 5'-tetramethylbenzidine (TMB, Solarbio, China) and the optical density (OD) at $450 \mathrm{~nm}$ was measured as previously reported (Xu et al., 2020b).

\section{Confocal microscopy}

The interaction between IECS and TSASP2 was also examined by IFT and confocal microscopy (Ren et al., 2018; Lei et al., 2020). IECs were grown on the cell culture plate until the confluence. rTsASP2 or MBP proteins $(20 \mu \mathrm{g} / \mathrm{ml})$ was added on the IECs and cultured for $2 \mathrm{~h}$. The IECs were fixed with paraformaldehyde, and following blocked with $5 \%$ normal goat serum. After incubating with anti-rTsASP2 serum, immune serum against maltose-binding protein (MBP) tag or normal serum for $1 \mathrm{~h}$, the IECS were stained with FITC-conjugated anti-mouse IgG for another hour. To analyze influence of rTsASP2 protease activity on the interaction, an aspartic protease specific inhibitor-pepstain $A$ was used to preincubate with $r T S A S P 2$. The IEC nuclei were stained with propidium iodide $(\mathrm{PI})$. The results were observed under confocal microscopy (Song et al., 2018a; Yan et al., 2020).

\section{Immunization regimen and evaluation of systemic immune response}

Four groups of male BALB/C mice (40 animals each group) were used in this study. The first group of mice was immunized subcutaneously with $20 \mu \mathrm{g}$ of rTsASP2 emulsified in ISA201 adjuvant and two booster immunization was performed using the same method at a 2- week-interval. Other three groups were subcutaneously immunized with MBP protein emulsified in ISA201, only ISA20 adjuvant or PBS 
alone using the same vaccination scheme (Long et al., 2014; Yue et al., 2020). To evaluate the induced systemic responses, serum samples were collected from vaccinated mice at weeks 0, 2, 4 and 6 after immunization.

The levels of anti-rTsASP2 antibodies (total IgG, IgG1 and IgG2a) in serum samples of immunized mice were determined by ELISA with IIL crude proteins (Sun et al., 2019a; Hu et al., 2020a). Briefly, the plates were coated with IIL crude proteins $(0.25 \mathrm{\mu g} / \mathrm{ml})$ at $4^{\circ} \mathrm{C}$ overnight. After blocking with $5 \%$ skimmed milk, the plates were incubated with immune serum (1:100 dilution). Then HRP-conjugated goat anti-mouse IgG, IgG1 or IgG2a were added and incubated at $37^{\circ} \mathrm{C}$ for $1 \mathrm{~h}$. O-phenylenediamine dihydrochloride (OPD) was used as substrate and the reaction was terminated with $2 \mathrm{M} \mathrm{H}_{2} \mathrm{SO}_{4}$. The absorbance at $450 \mathrm{~nm}$ was measured using a microplate reader (Xu et al., 2020b).

\section{ELISA determination of intestinal total and specific sIgA}

To determine total and TsASP2-specific slgA in enteric fluid, enteric washings were collected as previously reported (Bermudez-Cruz et al., 2016; Sun et al., 2019b). In brief, a 20-cm long of enteric segment was dissected, and the enteric interior was eluted with cold PBS with $1 \%$ protease inhibitor PMSF (Sangon Biotech, Shanghai, China). The washing were recovered, centrifuged at $5000 \mathrm{~g}$ for $5 \mathrm{~min}$, and the supernatants were collected (Li et al., 2018). Enteral total and specific slgA was measured as described before (Zhang et al., 2020a).

\section{Cytokine determination}

To ascertain the specific cellular immune responses against rTsASP2 immunization, the spleens and mesenteric lymph nodes (MLNs) were isolated from immunized mice at $0,2,4$, 6 weeks post vaccination (Qi et al., 2018; Zhang et al., 2020a). The splenocytes and MLN cells were prepared in the DMEM medium and their density were adjusted to $2 \times 10^{5}$ cells $/ \mathrm{ml}$. After the cells were stimulated with $\mathrm{rTsASP} 2$ at a concentration of $3 \mu \mathrm{g} / \mathrm{ml}$ at $37^{\circ} \mathrm{C}$ for $72 \mathrm{~h}$, the culture supernatant was collected and the concentrations of cytokines (IFN- $\gamma$ and IL-4) were measured using a sandwich ELISA method (PompaMera et al., 2014; Zhang et al., 2020b).

\section{Larval challenge experiment}

Two weeks after the last immunization, all vaccinated mice were challenged orally with $300 \mathrm{~T}$. spiralis ML. Intestinal AWs were recovered from ten mice each group 6 days after challenge. The muscle larvae were examined in remaining 10 mice from each group at $35 \mathrm{dpi}$ (Liu et al., 2015a). The worm reduction rate was calculated based on the number of AW or larvae per gram (LPG) of skeletal muscles collected from immunized group versus those from the PBS control group (Wang et al., 2018; Yang et al., 2020).

\section{Statistical analysis}

Data were represented as the means \pm standard deviation (SD). The statistical analyses were performed with One-way ANOVA and student's $t$-test using SPSS version 19.0 software. $P<0.05$ was considered as statistically significant.

\section{RESULTS}

\section{Aspartic protease activity of $T$. spiralis at different stages}

To determine the enzymatic activity of native aspartic protease in various $T$. spiralis worm stages, a specific fluorogenic synthetic substrate was incubated with crude proteins of various $T$. spiralis worm stages. The results showed that aspartic protease activities in intestinal stage worms ( 6 hours-3 days) were significantly higher than that in the ML stage (Figure 1) $(P<0.05)$. The aspartic protease activity was scarcely detected in NBL stage.

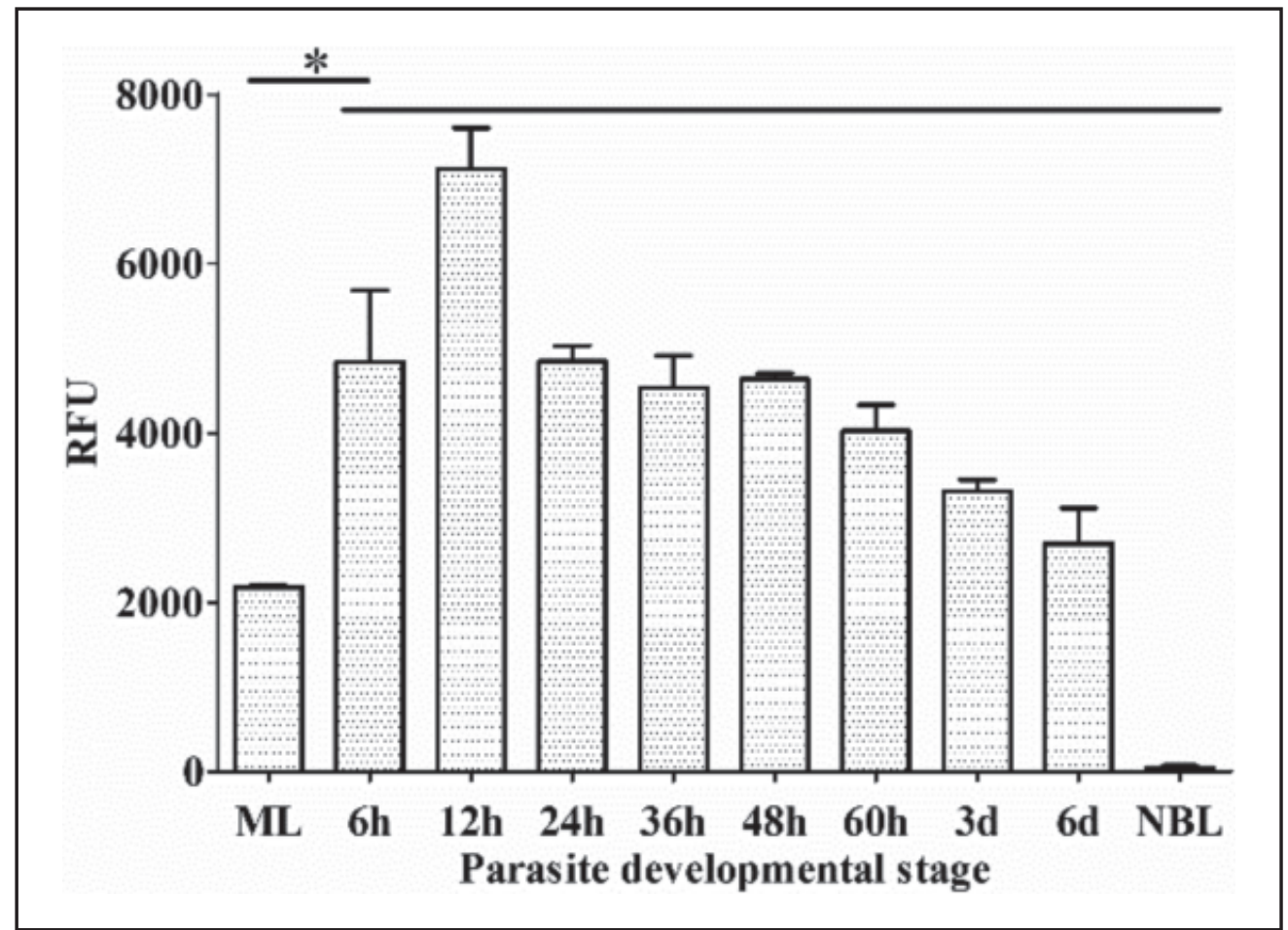

Figure 1. Analysis of aspartic protease activity in crude protein of $T$. spiralis at various stages. Asterisks indicate a statistically significant difference compared with the $\mathrm{ML}$ stage $(P<0.05)$. RFU, relative fluorescence units. 
TsASP2 expression level at different $T$. spiralis stage worms TsASP2 mRNA transcript (1280 bp) at different $T$. spiralis stage worms was amplified by using RT-PCR method (Figure 2A). The control gene GAPDH (580 bp) was also observed at diverse worm phases (Figure 2B). Surprisingly, Western blot analysis revealed that TsASP2 protein was expressed in $\mathrm{ML}$, IIL and AW stages but not in NBL stage. The TsASP2 expression level at IIL stage was significantly higher than those in other worm stages (ML, 3-day and 6-day adults, and NBL) $(P<0.05)$ (Figure 2C).

Expression and Localization of TsASP2 at different stage worms by IFT

Expression and localization of TSASP2 in different $T$. spiralis phases were investigated using IFT. The results showed that native TsASP2 was localized at the muscle cells, stichosome and midgut of $\mathrm{ML}$ and IIL, and around the embryos in the female AWs, but no immunostaining was detected in NBL cross-section (Figure 3).

Specific binding between TSASP2 and IECs protein measured by ELISA

The binding between rTSASP2 and IEC protein was confirmed by ELISA. The results showed that the OD values have a dosedependent relationship with IEC proteins and revealed an elevating trend with the increasing IEC coating concentration. Furthermore, the OD values were also dose dependent on rTSASP2 and displayed an elevating trend with increasing rTsASP2 concentration (Figure 4).

\section{Localization of rTsASP2 binding with IECs}

The binding and cellular localization of RTSASP2 with IECS were detected by IFT with anti-rTsASP2 serum, but not by normal serum. No immunostaining was detected between MBP proteins and IECs, and rTsASP2 and C2C12 cells (Figure 5). Confocal microscopy showed that the binding between rTSASP2 and IECs was located at the cytomembrane of IECS (Figure 6). After rTsASP2 was pre-incubated with pepstain A, the staining intensity became weaken, suggesting that the binding of rTSASP2 and IECS was inhibited by the aspartic protease specific inhibitor pepstain $A$.
Humoral and mucosal responses

Serum specific anti-rTsASP2 antibody IgG level was obviously elevated following the first immunization compared with three control groups $(P<0.05)$ (Figure $7 \mathrm{~A})$, demonstrating that rTsASP2 possesses good immunogenic. The IgG1 levels on weeks 2, 4 and 6 post immunization was significantly higher than IgG2a $\left(t_{2 \mathrm{w}}=8.438, t_{4 \mathrm{w}}=16.451, t_{6 \mathrm{w}}=12.489, P<0.0001\right)$ (Figure 7B), suggesting that the Th1/Th2-mixed type of immune response was elicited by rTsASP2 immunization, and the Th2 response was dominant.

Furthermore, rTsASP2 also elicited the enteral mucosal slgA response. Total slgA level was evidently higher in TsASP2immunized mice than that in mice inoculated with $M B P$, ISA201 and PBS alone (Figure $7 C)\left(F_{2 w}=525.778, F_{4 w}=278.873\right.$, $F_{6 \mathrm{w}}=106.814, P<0.0001$ ) (Fig. 7C). Similarly, TsASP2-specific slgA level was significantly higher than the three control groups (Figure 7D) $\left(F_{2 \mathrm{w}}=67.589, F_{4 \mathrm{w}}=149.162, F_{6 \mathrm{w}}=300.25\right.$, $P<0.0001)$.

\section{Cytokine responses}

To examine the cytokines secreted by MLN and spleen of mice immunized with rTsASP2, the cytokine levels of IFN- $\gamma$ and IL-4 were measured by ELISA. Compared with MBP, ISA201 and PBS control groups, the IFN- $\gamma$ levels in spleen and MLNs of rTsASP2 immunized mice were significantly increased at 4 and 6 weeks after first immunization $(P<0.0001)$, and IL-4 levels were evidently elevated at 2, 4 and 6 weeks following immunization $(P<0.0001)$ (Figure 8$)$.

\section{Immune protection}

To investigate the protective efficacy of rTsASP2 immunization against $T$. spiralis infection, the intestinal adult worm, NBL production and muscle larval burden were examined in all vaccinated mice. Compared with the PBS group, the rTsASP2immunized mice showed a $54.58 \%$ reduction in adult worms at 6 dpi $(F=26.72, P<0.0001)$ and $54.17 \%$ reduction in muscle larvae at $35 \mathrm{dpi}$ (Figure 9) $(F=37.811, P<0.0001)$. Furthermore, the production of NBL by the female adults from rTsASP2immunized mice was evidently decreased compared with the other three control groups $(F=20.476, P<0.0001)$.

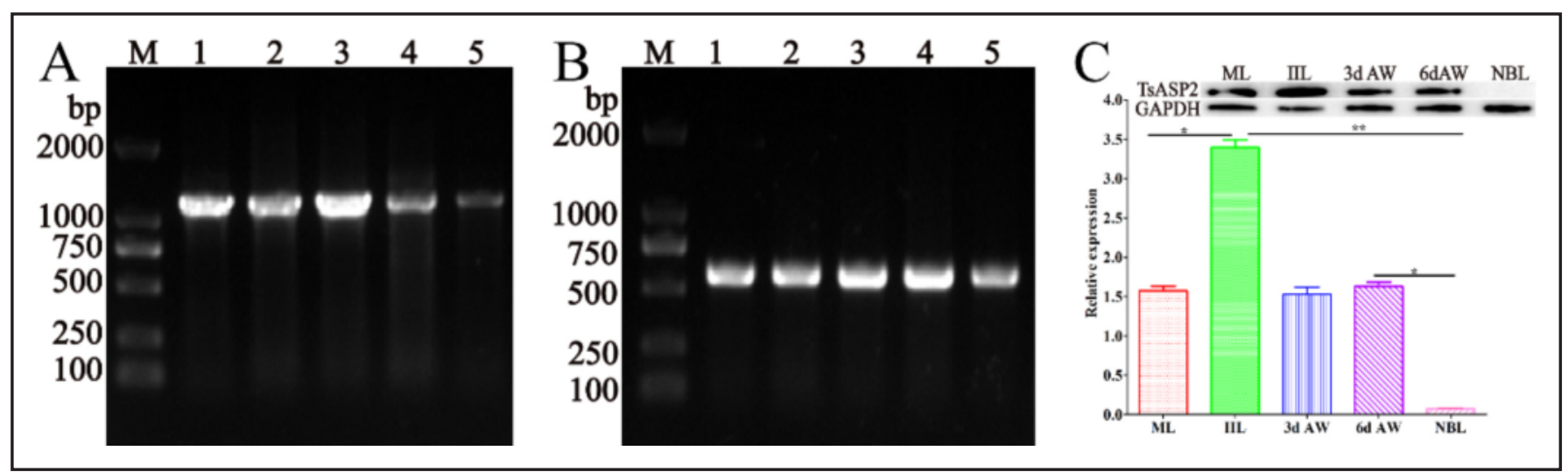

Figure 2. RT-PCR and Western blotting analysis of TSASP2 expression level at diverse $T$. spiralis phases. A, B: RT-PCR analysis of TsASP2 transcription. A: TsASP2 gene (1780 bp); B: GAPDH (570 bp); M: DL2000 DNA marker; lane 1: ML; lane 2: IIL; lane 3: 3 d AWs; lane 4: $6 \mathrm{~d}$ AWs; lane 5: NBL. C: Western blotting of TSASP2 expression in diverse T. spiralis stages based on three independent densitometry measurement. The relative expression level of TSASP2 in IIL the stage was significantly higher than those in other worm stages $(* P<0.05)$. 


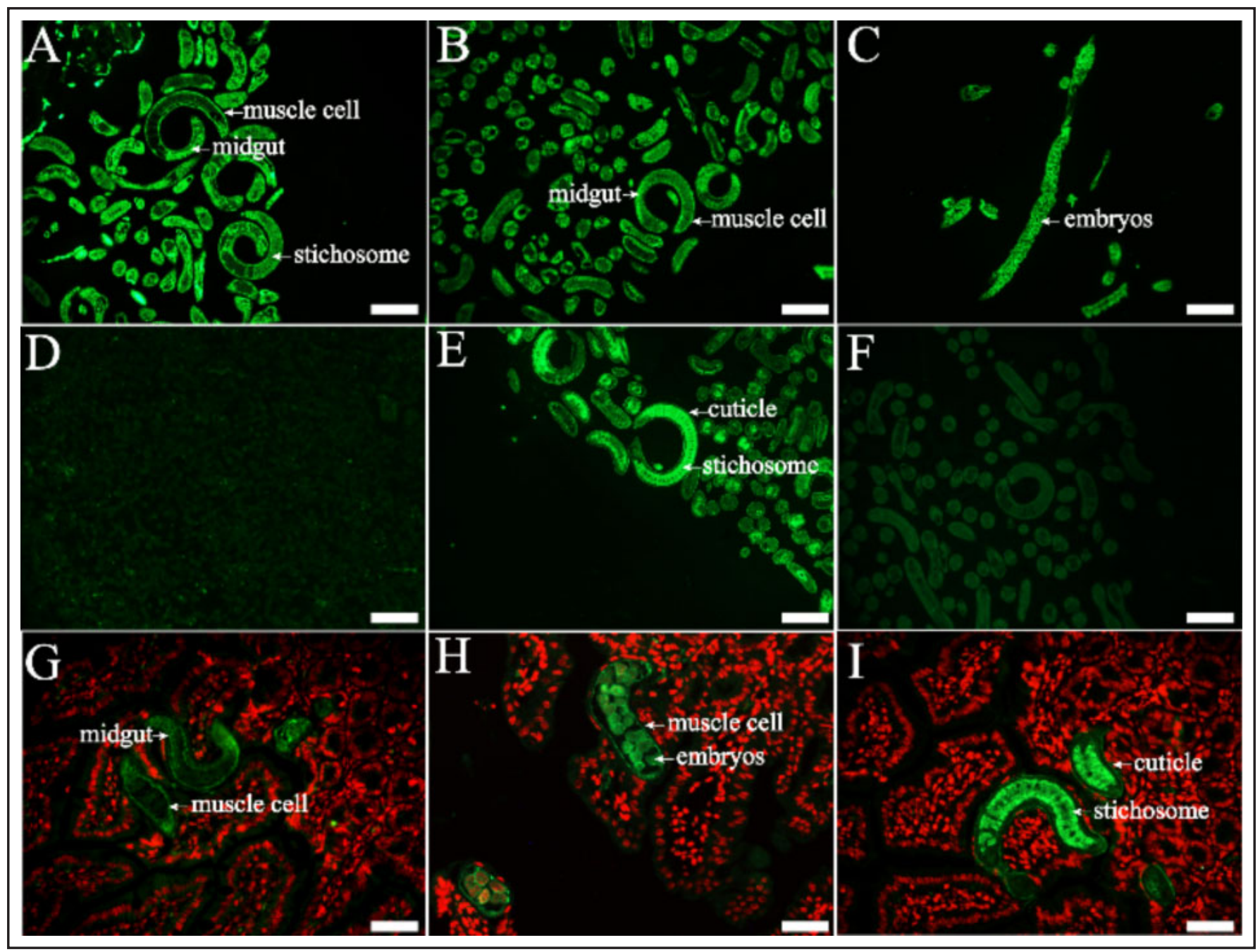

Figure 3. Immunolocalization of TSASP2 at various $T$. spiralis phases. The cross-sections of various $T$. spiralis phases including ML (A), IIL (B), AW (C) and NBL (D) and intestinal sections from infected mice at $6 \mathrm{hpi}(\mathrm{G})$ and $3 \mathrm{dpi}(\mathrm{H})$ were probed by anti-rTsASP2 serum. Fluorescence stating was observed at stichosome, muscle cells and midgut of $\mathrm{ML}$ and IIL, and surround the embryos of female AW. ML (E) and intestinal section at $6 \mathrm{hpi} \mathrm{(I)} \mathrm{were} \mathrm{incubated} \mathrm{by} \mathrm{infection} \mathrm{serum} \mathrm{as} \mathrm{a} \mathrm{positive} \mathrm{control;} \mathrm{ML} \mathrm{(F)} \mathrm{incubated}$ with normal serum as a negative control. Scale bars: $100 \mu \mathrm{m}$.

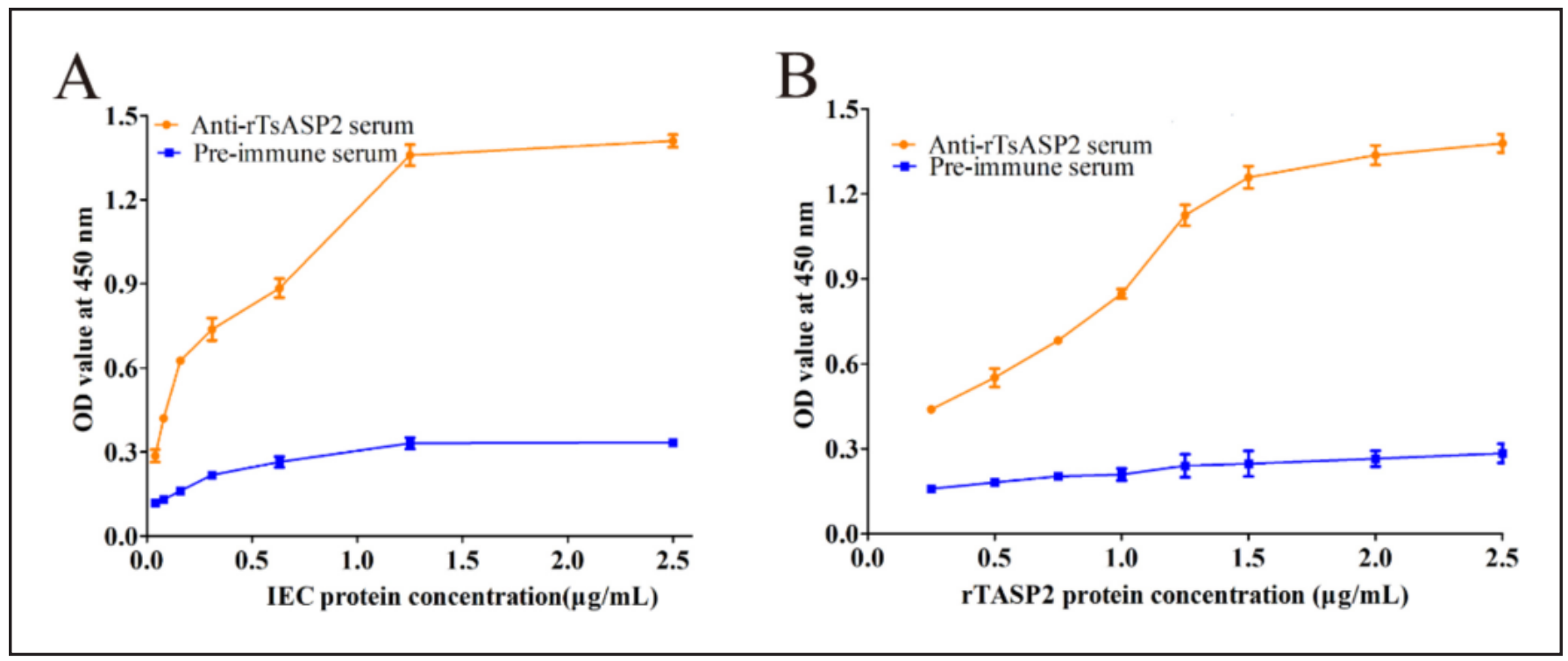

Figure 4. Binding ability of $r$ TsASP2 with IECs measured by ELISA. A. Binding between $10 \mu \mathrm{g} / \mathrm{ml} \mathrm{rTs} A S P 2$ and various concentrations of IEC proteins. B. Binding between IEC proteins $(5 \mu \mathrm{g} / \mathrm{ml})$ and various concentrations of rTsASP2. The binding of rTsASP2 with IEC protein is dose-dependently related to rTSASP2 and IEC protein. 


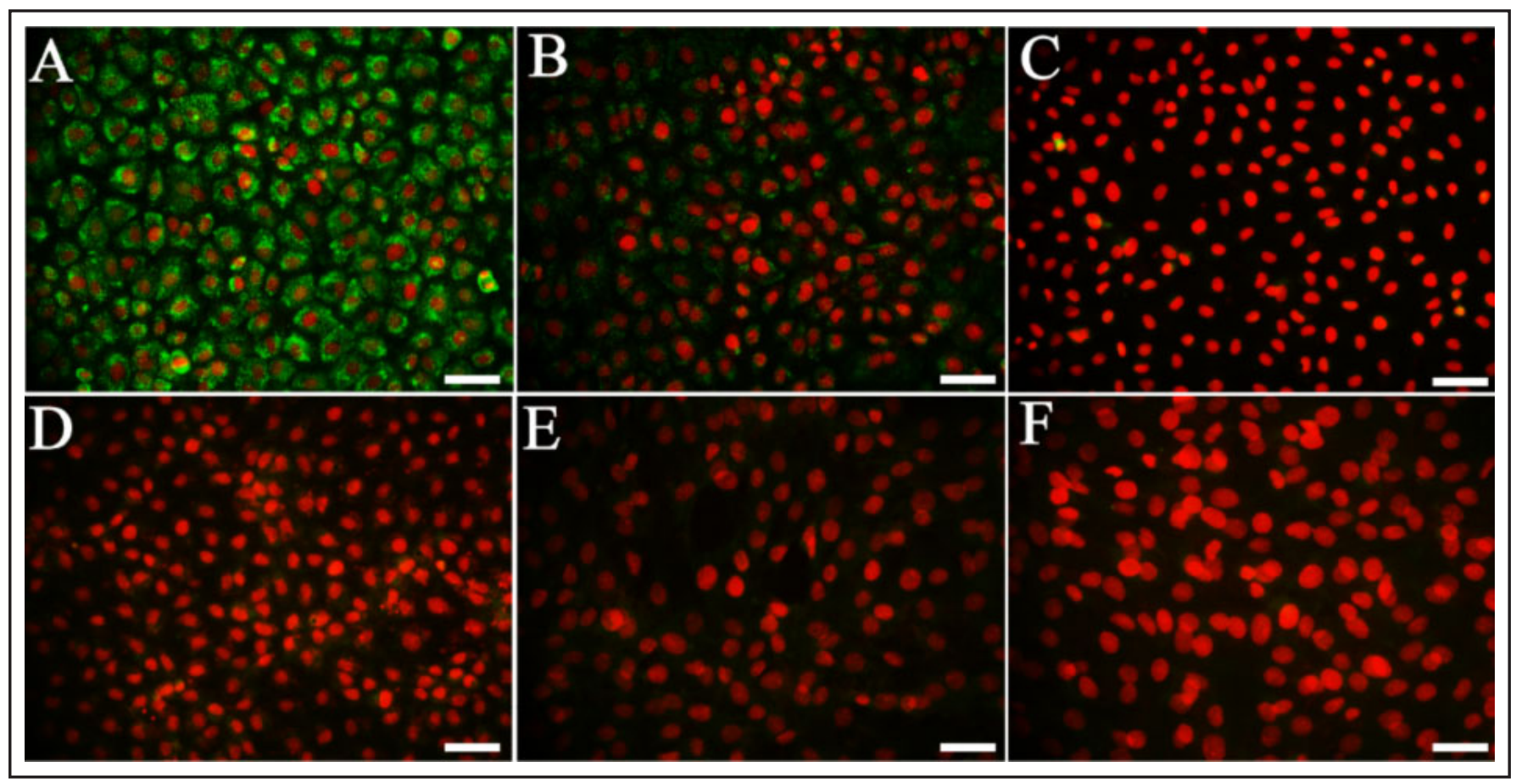

Figure 5. Specific binding between rTSASP2 and IEC analyzed by IFT. A-D: IECs; E-F: C2C12 cells. A: IECs were incubated with rTsASP2 and then probed with anti-rTsASP2 serum. B: IECs were incubated with rTsASP2 pre-incubated with pepstain A and then probed with anti-rTsASP2 serum; C: IECs were incubated with rTSASP2 and then probed with normal serum. D: IECs were incubated with MBP protein and probed with anti-MBP serum. E: C2C12 cells were with rTsASP2 and probed with anti-rTsASP2 serum. F: C2C12 cells were incubated with MBP protein and probed with anti-MBP serum. Scale bars: $50 \mu \mathrm{m}$.

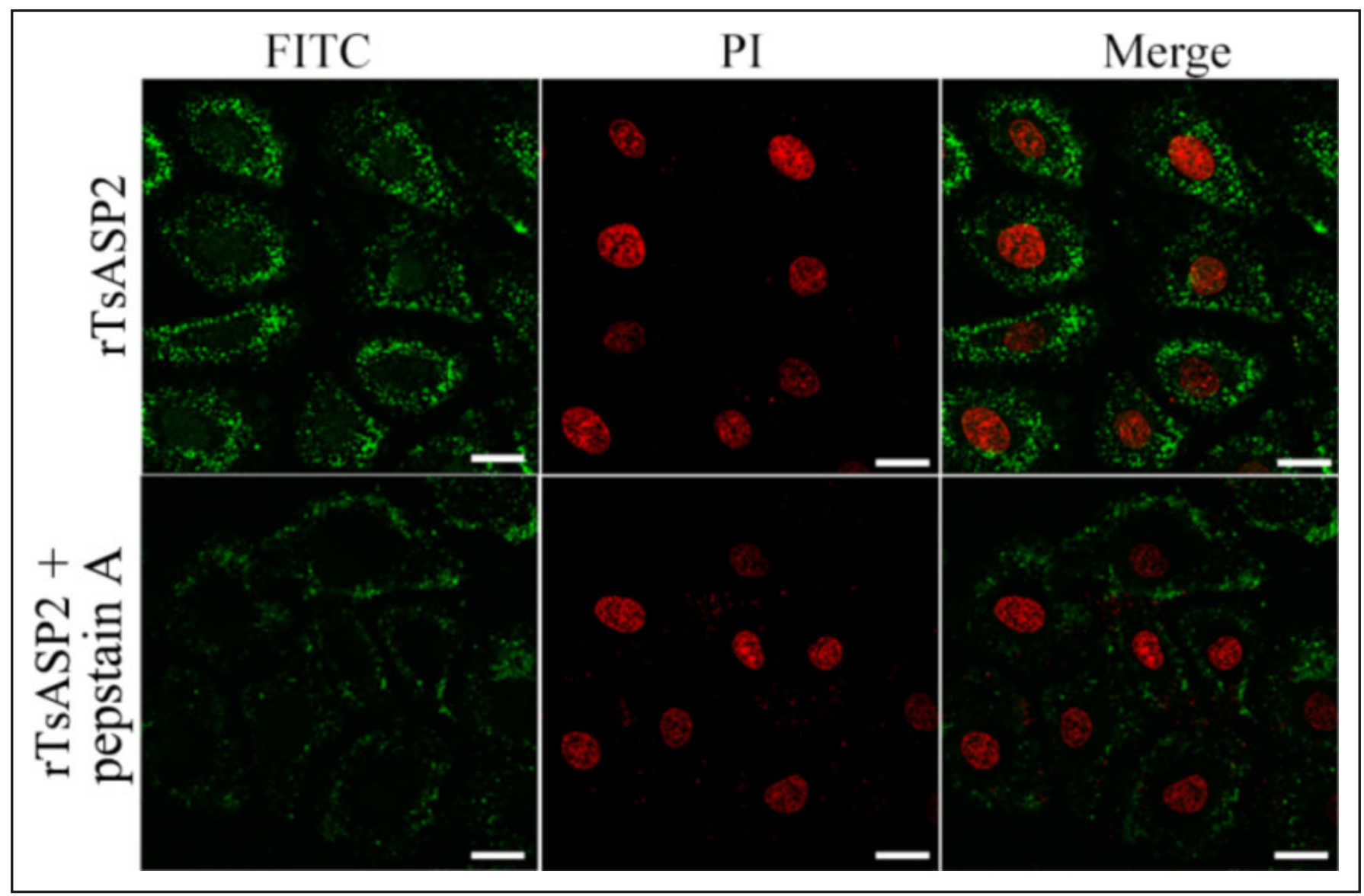

Figure 6. Cellular localization of rTSASP2 binding with IECS under confocal microscopy. The IECs were first incubated with rTsASP2 alone or rTsASP2 pre-treated with pepstain A, and then probed with anti-rTsASP2 serum. Immunostaining was observed in the cytomembrane and partial cytoplasm in IECS when the IECS were incubated with rTSASP2. When the IECs were incubated with rTsASP2 pre-treated with pepstain A, less immunostaining was observed. Scale bars: $20 \mu \mathrm{m}$. 


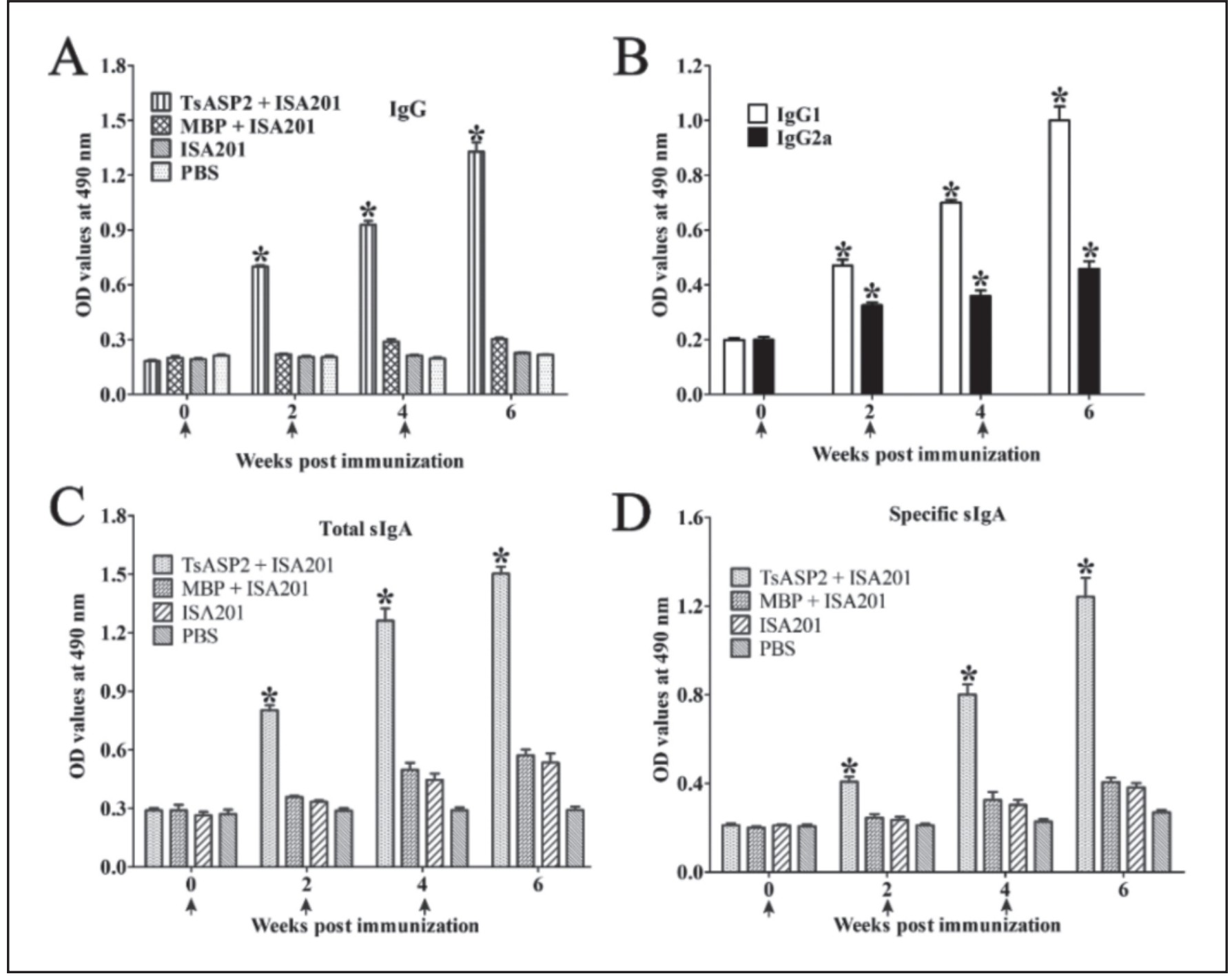

Figure 7. Analysis of anti-rTsASP2 IgG and sIgA responses in mice vaccinated with rTsASP2. A: anti-rTsASP1 IgG levels in serum of immunized mice at various time intervals after immunization. B: the IgG subclass response of immunized mice at diverse time intervals after immunization. C: total intestinal slgA. D: TsASP2-specific slgA. The data are shown as the mean OD values \pm SD for 20 mice per group for IgG and IgG1/IgG2a, and 5 mice for total sIgA and TsASP1-specific slgA. No detectable specific slgA was observed in mice inoculated with only MBP, adjuvant or PBS. Arrows $(\uparrow)$ indicate the vaccination times. ${ }^{*} P<0.0001$ compared with the MBP, adjuvant and PBS group.

\section{DISCUSSION}

Aspartic proteases are one of the most important families of proteases and have been identified in numerous parasites. They play the important roles in parasitic infection, such as larval invasion, digestion and proteolysis (Tcherepanova et al., 2000; Jolodar et al., 2004). The aspartic proteases in adult parasites of Ancylostoma caninum and Necator camericanus can degrade host skin macromolecules, hemoglobin and serum proteins in a host-specific mode (Williamson et al., 2003a, 2003b). The T. spiralis aspartic protease had been identified in different worm phases (AW, $M L$, and IIL), and its function and enzymatic activity had also been characterized. The aspartic protease promoted the larval invasion of IECs and migration, suggesting that TSASP might play a key role for the degrading intercellular or other cytoplasmic proteins, and facilitating the larval invasion into IECs (Xu et al., 2020a, 2021).

In the present study, the enzymatic activities of TSASP2 were detected by incubation with the specific fluorogenic synthetic substrate and crude proteins of various $T$. spiralis stages, the results revealed that the highest activities were detected in the IIL stage, which was similar with the previous study (Xu et al., 2020a). This result was further confirmed by RT-PCR and Western blot, as both the TsASP2 mRNA and protein expression levels were the highest in IIL stage. Interestingly, the TSASP2 protein expression was scarcely detected in the NBL stage. The TSASP2 expression was observed by IFT at various stages of the nematode, and localized in the muscle cells and stichosome in the $M L$ and IIL and around the embryos in the female AW, but no immunostaining was seen in the NBL. These results might imply that the TSASP2 could play important functions at the IIL stage of $T$. spiralis, but not in the NBL stage.

ELISA was also employed in this study to ascertain the interactions between TSASP2 and IEC proteins. The binding between TSASP 2 and IEC proteins was the protein dosedependent as showed in Figure 4. The results of IFT and confocal microscopy showed that rTsASP2 can specifically bind to the IEC cytomembrance, and this binding was inhibited when TSASP2 was suppressed by specific inhibitor pepstain $A$, suggesting that the enzymatic activities of TsASP2 


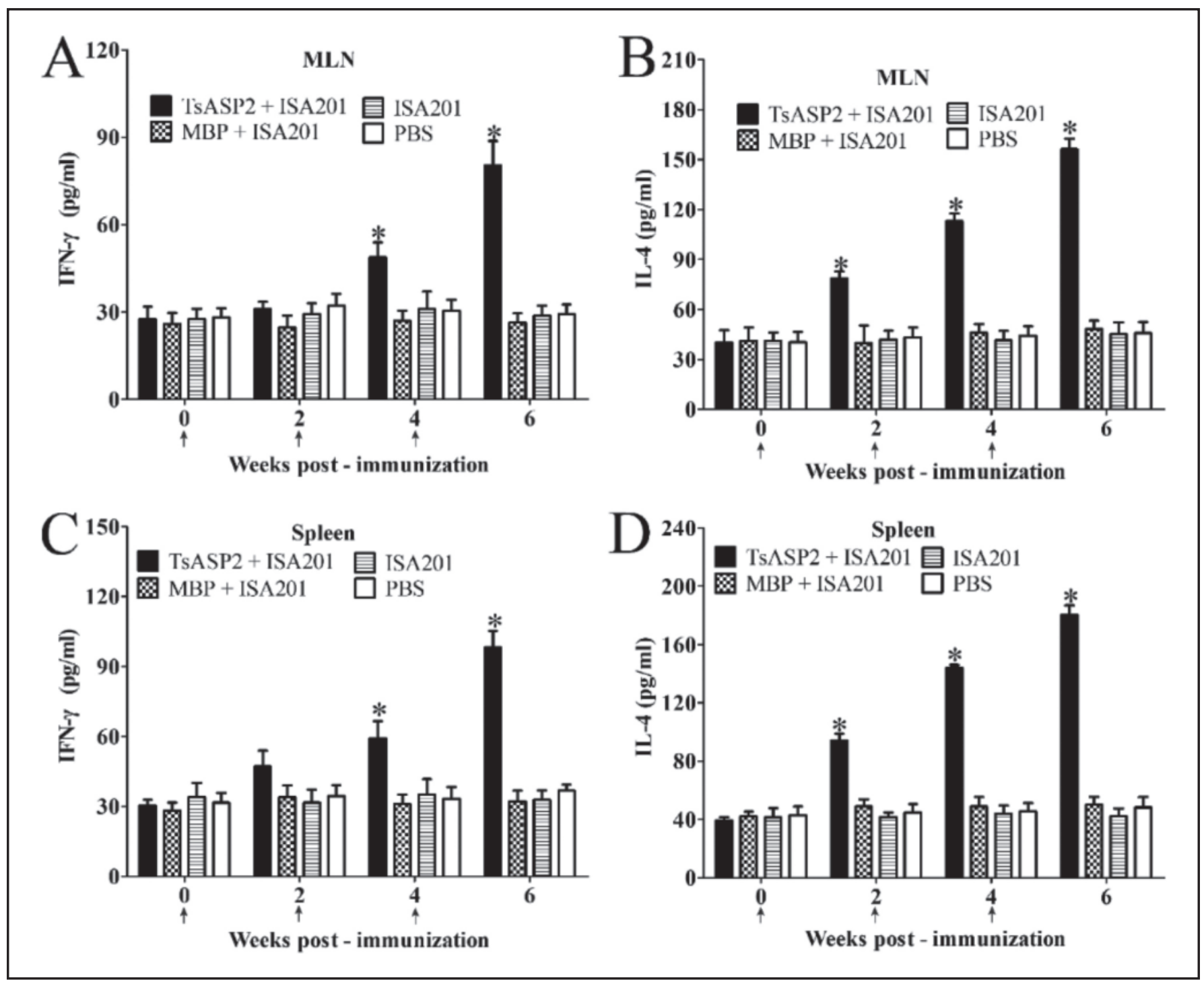

Figure 8. Cytokines secreted by splenocytes and MLN cells upon rTsASP2 re-stimulation. The concentrations of IFN- $\gamma(\mathbf{A}, \mathrm{C})$ and IL4 (B, D) were determined in the supernatant after spleen and MLN cells were stimulated by $4 \mu \mathrm{g}$ rTsASP2 for $72 \mathrm{~h}$. Arrows ( $\uparrow$ ) indicate the vaccination times. The asterisks $\left({ }^{*} P<0.05\right)$ indicate that statistically significant differences compared to the MBP, ISA201 and PBS control groups.

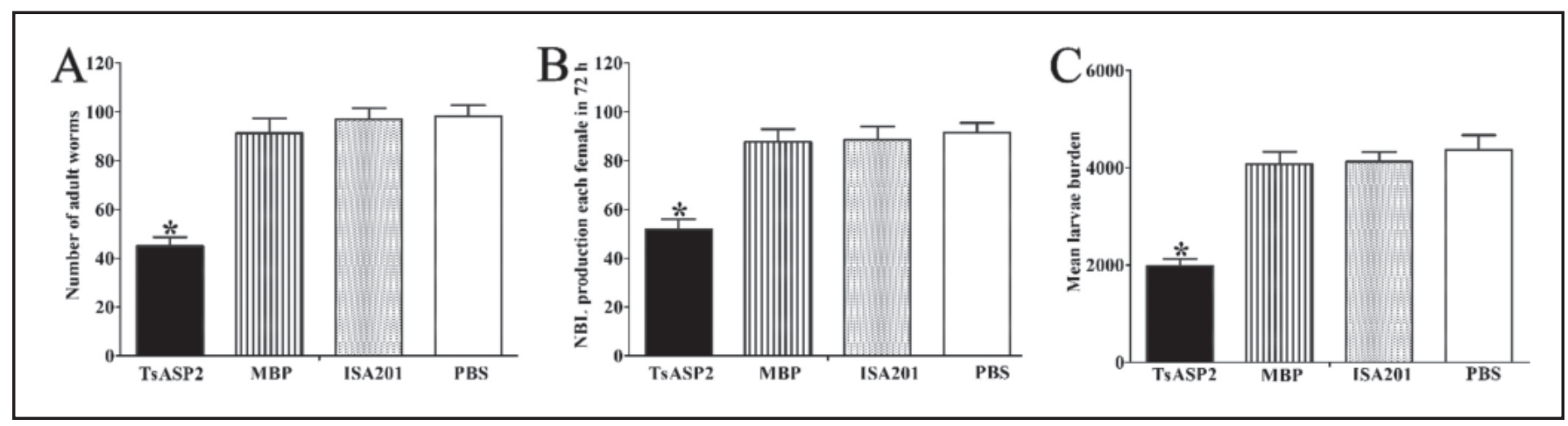

Figure 9. Immune protection of rTsASP2-immunized mice after being challenged with 300 T. spiralis larvae. A: Intestinal adult worm burden. B: The newborn larval production of each female cultured in vitro for $72 \mathrm{~h}$. C: Muscle larvae burden (larvae per gram, LPG). Result are presented as the mean \pm SD of ten mice each group. ${ }^{*} P<0.0001$ compared to the MBP, ISA201 and PBS groups. 
also participated in the interaction between rTSASP2 and IEC proteins (Long et al., 2015; Guo et al., 2020; Yan et al., 2020).

Vaccination of mice with rTsASP2 triggered specific humoral and mucosal immune responses, as demonstrated that both specific IgG and slgA levels were significantly elevated two weeks post vaccination. The IgG1 level was significantly higher than IgG2a, suggested that rTsASP2 emulsified in ISA201 adjuvant elicited a mixed IgG1/ IgG2a antibody response (Yang et al., 2019b; Zhang et al., 2020b). The antibody response was important for the protective immunity, but the cellular immunity was also crucial to defend T. spiralis infection (Cui et al., 2013b; Liu et al., 2015b). In this study, the cytokines of IFN- $\gamma$ and IL- 4 secreted by the splenocytes and MLN cells of mice vaccinated with rTsASP2 were significantly elevated. The production of IFN- $\gamma$ and IL-4 confirms that the immune responses induced by rTsASP2 vaccination were the mixed Th1/Th2 type. Previous studies have demonstrated that the concomitant Th1/Th2 immune responses were crucial for the protection against $T$. spiralis infection (Xu et al., 2017; Cui et al., 2019). Especially, the IL-4 is a critical mediator for the humoral immune response, and plays a crucial role in expulsion of $T$. spiralis by a Th2-type (Finkelman et al., 2004; Madden et al., 2004; Yang et al., 2010).

Vaccination of mice with rTSASP2 also induced the significant protection, as intestinal adult worms, NBL production and muscle larval burden in vaccinated mice was distinctly reduced. The immune protection (e.g., muscle larval burden reduction) induced by vaccination of rTsASP2 could be comparable with that of several recombinant $T$. spiralis proteins, such as cathepsin B (50.90\%; Cui et al., 2019), serine protease (52.10\%; Sun et al., 2018a), serine proteinase $(52.50 \%$; Yue et al., 2020), peptidase (41.93\%; Lei et al., 2020), elastase1 (64.06\%; Zhang et al., 2020), and TsASP1 (60.50\%; Xu et al., 2021). The reduction of the worm burden might be related with the Th1/Th2 immune response which may interrupt larval invasion of enterocytes, impair larval establishment and development in enteric epithelium (McVay et al., 2000; Song et al., 2018b). Previous studies suggested that antiTrichinella antibodies also participated in the damage and destruction of T. spiralis NBL through ADCC (Moskwa, 1999; Cui et al., 2015a; Zhang et al., 2020a). Our results demonstrated that the rTsASP2 might be a potential molecular target for anti-Trichinella vaccines.

In conclusion, TSASP2 was expressed at various $T$. spiralis stages, the highest expression level in the IIL stage, but not in the NBL. TSASP2 was principally localized at the muscle cells and stichosome of the ML and IIL and around the embryos in the female AW. The rTsASP2 was specially bound to the cytomembrane of IECs. Vaccination of mice with rTsASP2 induced a specific humoral and cellular immune responses, and significant protection. The TSASP 2 could be a candidate vaccine target molecule against $T$. spiralis infection.

\section{ACKNOWLEDGEMENTS}

This study was supported by grants of the National Natural Science Foundation of China (81871673, U1704284).

\section{Conflicts of interest}

The authors declare no conflicts of interest with regards to this study or the manuscript prepared for publication.

\section{REFERENCES}

Bai, X., Hu, X.X., Liu, X.L., Tang, B. \& Liu, M.Y. (2017). Current research of trichinellosis in China. Frontiers in Microbiology 8: 1472. https://doi.org/10.3389/fmicb.2017.01472
Bermudez-Cruz, R.M., Fonseca-Linan, R., Grijalva-Contreras, L.E., Mendoza-Hernandez, G. \& Ortega-Pierres, M.G. (2016). Proteomic analysis and immunodetection of antigens from early developmental stages of Trichinella spiralis. Veterinary Parasitology 231: 22-31. https://doi.org/10.1016/ j.vetpar.2016.06.029

Bien, J., Nareaho, A., Varmanen, P., Gozdzik, K., Moskwa, B., Cabaj, W., Nyman, T.A. \& Savijoki, K. (2012). Comparative analysis of excretory-secretory antigens of Trichinella spiralis and Trichinella britovi muscle larvae by twodimensional difference gel electrophoresis and immunoblotting. Proteome Science 10: 10. https://doi.org/10.1186/ 1477-5956-10-10

Bolas-Fernandez, F. \& Bezara, L.D. (2006). TSL-1 antigens of Trichinella: An overview of their potential role in parasite invasion, survival and serodiagnosis of trichinellosis. Research in Veterinary Science 81: 297-303. https://doi.org/ 10.1016/j.rvsc.2006.01.002

Cui, J., Han, Y., Yue, X., Liu, F., Song, Y.Y., Yan, S.W., Lei, J.J., Zhang, X., Jiang, P. \& Wang, Z.Q. (2019). Vaccination of mice with a recombinant novel cathepsin B inhibits Trichinella spiralis development, reduces the fecundity and worm burden. Parasites \& Vectors 12: 581. https://doi.org/10.1186/ s13071-019-3833-9

Cui, J., Jiang, P., Liu, L.N. \& Wang, Z.Q. (2013a). Survey of Trichinella infections in domestic pigs from northern and eastern Henan, China. Veterinary Parasitology 194: 133-135. https:// doi.org/10.1016/j.vetpar.2013.01.038

Cui, J., Li, L.G., Jiang, P., Liu, R.D., Yang, X., Liu, L.N., Liu, P., Zhang, S.B. \& Wang, Z.Q. (2015a). Biochemical and functional characterization of the glutathione Stransferase from Trichinella spiralis. Parasitology Research 114: 2007-2013. https://doi.org/10.1007/s00436-015-4410-6

Cui, J., Ren, H.J., Liu, R.D., Wang, L., Zhang, Z.F. \& Wang, Z.Q. (2013b). Phage-displayed specific polypeptide antigens induce significant protective immunity against Trichinella spiralis infection in BALB/c mice. Vaccine 31: 1171-1177. https://doi.org/10.1016/j.vaccine.2012.12.070

Cui, J., Wang, L., Sun, G.G., Liu, L.N., Zhang, S.B., Liu, R.D., Zhang, X., Jiang, P. \& Wang, Z.Q. (2015b). Characterization of a Trichinella spiralis $31 \mathrm{kDa}$ protein and its potential application for the serodiagnosis of trichinellosis. Acta Tropical 142: 57-63. https://doi.org/10.1016/j.actatropica. 2014.10.017

Cui, J., Wang, Z.Q. \& Xu, B.L. (2011). The epidemiology of human trichinellosis in China during 2004-2009. Acta Tropical 118: 1-5. https://doi.org/10.1016/j.actatropica.2011.02.005

Finkelman, F.D., Shea-Donohue, T., Morris, S.C., Gildea, L., Strait, R., Madden, K.B., Schopf, L. \& Urban, J.F., Jr. (2004). Interleukin-4- and interleukin-13-mediated host protection against intestinal nematode parasites. Immunological Reviews 201: 139-155. https://doi.org/10.1111/j.01052896.2004.00192.x

Guo, K.X., Bai, Y., Ren, H.N., Sun, X.Y., Song, Y.Y., Liu, R.D., Long, S.R., Zhang, X., Jiang, P., Wang, Z.Q. \& Cui, J. (2020). Characterization of a Trichinella spiralis aminopeptidase and its participation in invasion, development and fecundity. Veterinary Research 51: 78. https://doi.org/10.1186/ s13567-020-00805-w

Han, Y., Yue, X., Hu, C.X., Liu, F., Liu, R.D., He, M.M., Long, S.R., Cui, J. \& Wang, Z.Q. (2020). Interaction of a Trichinella spiralis cathepsin B with enterocytes promotes the larval intrusion into the cells. Research in Veterinary Science 130: 110-117. https://doi.org/10.1016/j.rvsc.2020.03.012

Hu, C.X., Jiang, P., Yue, X., Zeng, J., Zhang, X.Z., Song, Y.Y., Liu, R.D., Zhang, X., Wang, Z.Q. \& Cui, J. (2020a). Molecular characterization of a Trichinella spiralis elastase-1 and 
its potential as a diagnostic antigen for trichinellosis. Parasites \& Vectors 13: 97. https://doi.org/10.1186/s13071020-3981-y

Hu, C.X., Zeng, J., Yang, D.Q., Yue, X., Dan Liu, R., Long, S.R., Zhang, X., Jiang, P., Cui, J. \& Wang, Z.Q. (2020b). Binding of elastase-1 and enterocytes facilitates Trichinella spiralis larval intrusion of the host's intestinal epithelium. Acta Tropical 211: 105592. https://doi.org/10.1016/j.actatropica. 2020.105592

Jiang, P., Wang, Z.Q., Cui, J. \& Zhang, X. (2012). Comparison of artificial digestion and Baermann's methods for detection of Trichinella spiralis pre-encapsulated larvae in muscles with low-level infections. Foodborne Pathogens and Disease 9: 27-31. https://doi.org/10.1089/fpd.2011.0985

Jiang, P., Zhang, X., Wang, L.A., Han, L.H., Yang, M., Duan, J.Y., Sun, G.G., Qi, X. \& Liu, R.D. (2016). Survey of Trichinella infection from domestic pigs in the historical endemic areas of Henan province, central China. Parasitology Research 115: 4707-4709. https://doi.org/10.1007/s00436016-5240-x

Jolodar, A., Fischer, P., Buttner, D.W., Miller, D.J., Schmetz, C. \& Brattig, N.W. (2004). Onchocerca volvulus: expression and immunolocalization of a nematode cathepsin D-like lysosomal aspartic protease. Experimental Parasitology 107: 145-156. https://doi.org/10.1016/j.exppara.2004.06.006

Lei, J.J., Hu, Y.Y., Liu, F., Yan, S.W., Liu, R.D., Long, S.R., Jiang, P., Cui, J. \& Wang, Z.Q. (2020). Molecular cloning and characterization of a novel peptidase from Trichinella spiralis and protective immunity elicited by the peptidase in BALB/c mice. Veterinary Research 51: 111. https://doi.org/ 10.1186/s13567-020-00838-1

Li, J.F., Guo, K.X., Qi, X., Lei, J.J., Han, Y., Yan, S.W., Jiang, P., Yu, C., Cheng, X.C. \& Wang, Z.Q. (2018). Protective immunity against Trichinella spiralis in mice elicited by oral vaccination with attenuated Salmonella-delivered TsSP1.2 DNA. Veterinary Research 49: 87. https://doi.org/10.1186/ s13567-018-0582-2

Li, L.G., Wang, Z.Q., Liu, R.D., Yang, X., Liu, L.N., Sun, G.G., Jiang, P., Zhang, X., Zhang, G.Y. \& Cui, J. (2015). Trichinella spiralis: low vaccine potential of glutathione S-transferase against infections in mice. Acta Tropical 146: 25-32. https://doi.org/10.1016/j.actatropica.2015.02.020

Liu, C.Y., Ren, H.N., Song, Y.Y., Sun, G.G., Liu, R.D., Jiang, P., Long, S.R., Zhang, X., Wang, Z.Q. \& Cui, J. (2018). Characterization of a putative glutathione S-transferase of the parasitic nematode Trichinella spiralis. Experimental Parasitology 187: 59-66. https://doi.org/10.1016/j.exppara.2018.02.005

Liu, P., Cui, J., Liu, R.D., Wang, M., Jiang, P., Liu, L.N., Long, S.R., Li, L.G., Zhang, S.B. \& Zhang, X.Z. (2015a). Protective immunity against Trichinella spiralis infection induced by TsNd vaccine in mice. Parasites \& Vectors 8: 185. https:// doi.org/10.1186/s13071-015-0791-8

Liu, P., Wang, Z.Q., Liu, R.D., Jiang, P., Long, S.R., Liu, L.N., Zhang, X.Z., Cheng, X.C., Yu, C. \& Ren, H.J. (2015b). Oral vaccination of mice with Trichinella spiralis nudix hydrolase DNA vaccine delivered by attenuated Salmonella elicited protective immunity. Experimental Parasitology 153: 29-38. https:// doi.org/10.1016/j.exppara.2015.02.008

Liu, R.D., Cui, J., Liu, X.L., Jiang, P., Sun, G.G., Zhang, X., Long, S.R., Wang, L. \& Wang, Z.Q. (2015c). Comparative proteomic analysis of surface proteins of Trichinella spiralis muscle larvae and intestinal infective larvae. Acta Tropical 150: 79-86. https://doi.org/10.1016/j.actatropica.2015.07.002

Liu, R.D., Cui, J., Wang, L., Long, S.R., Zhang, X., Liu, M.Y. \& Wang, Z.Q. (2014). Identification of surface proteins of Trichinella spiralis muscle larvae using immunoproteomics. Tropical Biomedicine 31: 579-591.
Liu, R.D., Qi, X., Sun, G.G., Jiang, P., Zhang, X., Wang, L.A., Liu, X.L., Wang, Z.Q. \& Cui, J. (2016). Proteomic analysis of Trichinella spiralis adult worm excretory-secretory proteins recognized by early infection sera. Veterinary Parasitology 231: 43-46. https://doi.org/10.1016/j.vetpar.2016.10.008

Liu, R.D., Wang, Z.Q., Wang, L., Long, S.R., Ren, H.J. \& Cui, J. (2013). Analysis of differentially expressed genes of Trichinella spiralis larvae activated by bile and cultured with intestinal epithelial cells using real-time PCR. Parasitology Research 112: 4113-4120. https://doi.org/ 10.1007/s00436-013-3602-1

Long, S.R., Wang, Z.Q., Jiang, P., Liu, R.D., Qi, X., Liu, P., Ren, H.J., Shi, H.N. \& Cui, J. (2015). Characterization and functional analysis of Trichinella spiralis Nudix hydrolase. Experimental Parasitology 159: 264-273. https://doi.org/10.1016/j.exppara. 2015.10.009

Long, S.R., Wang, Z.Q., Liu, R.D., Liu, L.N., Li, L.G., Jiang, P., Zhang, X., Zhang, Z.F., Shi, H.N. \& Cui, J. (2014). Molecular identification of Trichinella spiralis nudix hydrolase and its induced protective immunity against trichinellosis in BALB/c mice. Parasites \& Vectors 7: 600. https://doi.org/ 10.1186/s13071-014-0600-9

Madden, K.B., Yeung, K.A., Zhao, A., Gause, W.C., Finkelman, F.D., Katona, I.M., Urban, J.F., Jr. \& Shea-Donohue, T. (2004). Enteric nematodes induce stereotypic STAT6-dependent alterations in intestinal epithelial cell function. Journal of Immunology 172: 5616-5621. https://doi.org/10.4049/ jimmunol.172.9.5616

Mantilla-Olea, M.I., Ortega-Lopez, J., Figueroa-Angulo, E.E., Avila-Gonzalez, L., Cardenas-Guerra, R.E., Miranda-Ozuna, J.F.T., Gonzalez-Robles, A., Hernandez-Garcia, M.S., Sanchez-Ayala, L. \& Arroyo, R. (2018). Trichomonas vaginalis cathepsin D-like aspartic proteinase (Tv-CatD) is positively regulated by glucose and degrades human hemoglobin. International Journal of Biochemistry \& Cell Biology 97: 1-15. https://doi.org/10.1016/j.biocel.2018.01.015

McVay, C.S., Bracken, P., Gagliardo, L.F. \& Appleton, J. (2000). Antibodies to tyvelose exhibit multiple modes of interference with the epithelial niche of Trichinella spiralis. Infection and Immunity 68: 1912-1918. https://doi.org/ 10.1128/iai.68.4.1912-1918.2000

Moskwa, B. (1999). Trichinella spiralis: in vitro cytotoxicity of peritoneal cells against synchronous newborn larvae of different age. Parasitology Research 85: 59-63. https:// doi.org/10.1007/s004360050507

Pompa-Mera, E.N., Arroyo-Matus, P., Ocana-Mondragon, A., Gonzalez-Bonilla, C.R. \& Yepez-Mulia, L. (2014). Protective immunity against enteral stages of Trichinella spiralis elicited in mice by live attenuated Salmonella vaccine that secretes a 30-mer parasite epitope fused to the molecular adjuvant C3d-P28. Research in Veterinary Science 97: 533545. https://doi.org/10.1016/j.rvsc.2014.09.010

Pozio, E. (2007). World distribution of Trichinella spp. infections in animals and humans. Veterinary Parasitology 149: 3-21. https://doi.org/10.1016/j.vetpar.2007.07.002

Qi, X., Han, Y., Jiang, P., Yue, X., Ren, H.N., Sun, G.G., Long, S.R., Yu, C., Cheng, X.C. \& Cui, J. (2018). Oral vaccination with Trichinella spiralis DNase II DNA vaccine delivered by attenuated Salmonella induces a protective immunity in BALB/c mice. Veterinary Research 49: 119. https://doi.org/ 10.1186/s13567-018-0614-y

Ren, H.J., Cui, J., Wang, Z.Q. \& Liu, R.D. (2011). Normal mouse intestinal epithelial cells as a model for the in vitro invasion of Trichinella spiralis infective larvae. Plos One 6: e27010. https://doi.org/10.1371/journal.pone.0027010 
Ren, H.J., Liu, R.D., Wang, Z.Q. \& Cui, J. (2013). Construction and use of a Trichinella spiralis phage display library to identify the interactions between parasite and host enterocytes. Parasitology Research 112: 1857-1863. https:// doi.org/10.1007/s00436-013-3339-x

Ren, H.N., Guo, K.X., Zhang, Y., Sun, G.G., Liu, R.D., Jiang, P., Zhang, X., Wang, L., Cui, J. \& Wang, Z.Q. (2018). Molecular characterization of a $31 \mathrm{kDa}$ protein from Trichinella spiralis and its induced immune protection in BALB/c mice. Parasites \& Vectors 11: 625. https://doi.org/10.1186/s13071018-3198-5

Rostami, A., Gamble, H.R., Dupouy-Camet, J., Khazan, H. \& Bruschi, F. (2017). Meat sources of infection for outbreaks of human trichinellosis. Food Microbiology 64: 65-71. https://doi.org/10.1016/j.fm.2016.12.012

Song, Y.Y., Zhang, Y., Ren, H.N., Sun, G.G., Qi, X., Yang, F., Jiang, P., Zhang, X., Cui, J. \& Wang, Z.Q. (2018a). Characterization of a serine protease inhibitor from Trichinella spiralis and its participation in larval invasion of host's intestinal epithelial cells. Parasites \& Vectors 11: 499. https://doi.org/ 10.1186/s13071-018-3074-3

Song, Y.Y., Zhang, Y., Yang, D., Ren, H.N., Sun, G.G., Jiang, P., Liu, R.D., Zhang, X., Cui, J. \& Wang, Z.Q. (2018b). The immune protection induced by a serine protease inhibitor from the foodborne parasite Trichinella spiralis. Frontiers in Microbiology 9: 1544. https://doi.org/10.3389/fmicb.2018. 01544

Sun, G.G., Lei, J.J., Guo, K.X., Liu, R.D., Long, S.R., Zhang, X., Jiang, P., Cui, J. \& Wang, Z.Q. (2019a). Primary assessment of a $T$. spiralis putative serine protease for early serological detection of experimental trichinellosis. Tropical Biomedicine 36: 792-802.

Sun, G.G., Lei, J.J., Ren, H.N., Zhang, Y., Guo, K.X., Long, S.R., Liu, R.D., Jiang, P., Wang, Z.Q. \& Cui, J. (2019b). Intranasal immunization with recombinant Trichinella spiralis serine protease elicits protective immunity in BALB/c mice. Experimental Parasitology 201: 1-10. https://doi.org/10.1016/ j.exppara.2019.04.006

Sun, G.G., Liu, R.D., Wang, Z.Q., Jiang, P., Wang, L., Liu, X.L., Liu, C.Y., Zhang, X. \& Cui, J. (2015). New diagnostic antigens for early trichinellosis: the excretory-secretory antigens of Trichinella spiralis intestinal infective larvae. Parasitology Research 114: 4637-4644. https://doi.org/10.1007/s00436015-4709-3

Sun, G.G., Ren, H.N., Liu, R.D., Song, Y.Y., Qi, X., Hu, C.X., Yang, F., Jiang, P., Zhang, X. \& Wang, Z.Q. (2018a). Molecular characterization of a putative serine protease from Trichinella spiralis and its elicited immune protection. Veterinary Research 49: 59. https://doi.org/10.1186/s13567018-0555-5

Sun, G.G., Song, Y.Y., Jiang, P., Ren, H.N., Yan, S.W., Han, Y., Liu, R.D., Zhang, X., Wang, Z.Q. \& Cui, J. (2018b). Characterization of a Trichinella spiralis putative serine protease. Study of its potential as sero-diagnostic tool. PloS Neglected Tropical Diseases 12. https://doi.org/10.1371/journal.pntd.0006485

Tcherepanova, I., Bhattacharyya, L., Rubin, C.S. \& Freedman, J.H. (2000). Aspartic proteases from the nematode Caenorhabditis elegans. Structural organization and developmental and cell-specific expression of asp-1. Journal of Biological Chemistry 275: 26359-26369. https:// doi.org/10.1074/jbc.M000956200

Wang, B., Wang, Z.Q., Jin, J., Ren, H.J., Liu, L.N. \& Cui, J. (2013a). Cloning, expression and characterization of a Trichinella spiralis serine protease gene encoding a $35.5 \mathrm{kDa}$ protein. Experimental Parasitology 134: 148-154. https://doi.org/ 10.1016/j.exppara.2013.03.004
Wang, J.Z., Jiang, Y.L., Yang, W.T., Shi, C.W., Huang, H.B., Sun, H., Liu, G.S., Wang, C.F., Yang, G.L. \& Cai, Y.A. (2018). Vaccination with DNA encoding ES 43-kDa/45-kDa antigens significantly reduces Trichinella spiralis infection in mice. Research in Veterinary Science 120: 4-10. https://doi.org/10.1016/ j.rvsc.2018.08.002

Wang, L., Cui, J., Hu, D.D., Liu, R.D. \& Wang, Z.Q. (2014). Identification of early diagnostic antigens from major excretory-secretory proteins of Trichinella spiralis muscle larvae using immunoproteomics. Parasites \& Vectors 7: 40. https://doi.org/10.1186/1756-3305-7-40

Wang, L., Wang, Z.Q. \& Cui, J. (2013b). Proteomic analysis of the changed proteins of Trichinella spiralis infective larvae after co-culture in vitro with intestinal epithelial cells. Veterinary Parasitology 194: 160-163. https://doi.org/10.1016/ j.vetpar.2013.01.045

Wang, Z.Q., Li, L.Z., Jiang, P., Liu, L.N. \& Cui, J. (2012). Molecular identification and phylogenetic analysis of Trichinella isolates from different provinces in mainland China. Parasitology Research 110: 753-757. https://doi.org/10.1007/ s00436-011-2549-3

Wang, Z.Q., Liu, R.D., Sun, G.G., Song, Y.Y., Jiang, P., Zhang, X. \& Cui, J. (2017). Proteomic analysis of Trichinella spiralis adult worm excretory-secretory proteins recognized by sera of patients with early trichinellosis. Frontiers in Microbiology 8: 986. https://doi.org/10.3389/fmicb.2017.00986

Williamson, A.L., Brindley, P.J., Abbenante, G., Datu, B.J.D., Prociv, P., Berry, C., Girdwood, K., Pritchard, D.I., Fairlie, D.P. \& Hotez, P.J. (2003a). Hookworm aspartic protease, NaAPR-2, cleaves human hemoglobin and serum proteins in a host-specific fashion. Journal of Infectious Diseases 187: 484-494. https://doi.org/10.1086/367708

Williamson, A.L., Brindley, P.J. \& Loukas, A. (2003b). Hookworm cathepsin $D$ aspartic proteases: contributing roles in the host-specific degradation of serum proteins and skin macromolecules. Parasitology 126: 179-185. https://doi.org/ 10.1017/s0031182002002706

Wu, Z., Nagano, I., Takahashi, Y. \& Maekawa, Y. (2016). Practical methods for collecting Trichinella parasites and their excretory-secretory products. Parasitology International 65: 591-595. https://doi.org/10.1016/j.parint.2016.08.001

Xu, J., Bai, X., Wang, L.B., Shi, H.N., Van Der Giessen, J.W.B., Boireau, P., Liu, M.Y. \& Liu, X.L. (2017). Immune responses in mice vaccinated with a DNA vaccine expressing serine protease-like protein from the new-born larval stage of Trichinella spiralis. Parasitology 144: 712-719. https://doi.org/ 10.1017/S0031182016002493

Xu, J., Liu, R.D., Bai, S.J., Hao, H.N., Yue, W.W., Xu, Y.X.Y., Long, S.R., Cui, J. \& Wang, Z.Q. (2020a). Molecular characterization of a Trichinella spiralis aspartic protease and its facilitation role in larval invasion of host intestinal epithelial cells. PLoS Neglected Tropical Diseases 14: e0008269. https:// doi.org/10.1371/journal.pntd.0008269

Xu, J., Liu, R.D., Long, S.R., Song, Y.Y., Jiang, P., Zhang, X., Cui, J. \& Wang, Z.Q. (2020b). Characterization of a chymotrypsinlike enzyme from Trichinella spiralis and its facilitation of larva penetration into the host's enteral epithelial cells. Research in Veterinary Science 128: 1-8. https://doi.org/ 10.1016/j.rvsc.2019.10.018

Xu, J., Yang, F., Yang, D.Q., Jiang, P., Liu, R.D., Zhang, X., Cui, J. \& Wang, Z.Q. (2018). Molecular characterization of Trichinella spiralis galectin and its participation in larval invasion of host's intestinal epithelial cells. Veterinary Research 49: 79. https://doi.org/10.1186/s13567-018-0573-3 
Xu, J., Yue, W.W., Xu, Y.X.Y., Hao, H.N., Liu, R.D., Long, S.R., Wang, Z.Q. \& Cui, J. (2021). Molecular characterization of a novel aspartyl protease-1 from Trichinella spiralis. Research in Veterinary Science 134: 1-11. https://doi.org/10.1016/ j.rvsc.2020.11.008

Yan, S.W., Hu, Y.Y., Song, Y.Y., Ren, H.N., Shen, J.M., Liu, R.D., Long, S.R., Jiang, P., Cui, J. \& Wang, Z.Q. (2020). Characterization of a Trichinella spiralis cathepsin $\mathrm{X}$ and its promotion for the larval invasion of mouse intestinal epithelial cells. Veterinary Parasitology 109160. https:// doi.org/10.1016/j.vetpar.2020.109160

Yang, F., Guo, K.X., Yang, D.Q., Liu, R.D., Long, S.R., Zhang, X., Jiang, P., Cui, J. \& Wang, Z.Q. (2020). Functional analysis of Trichinella spiralis serine protease 1.2 by siRNA mediated RNA interference. Tropical Biomedicine 37: 458-470.

Yang, F., Yang, D.Q., Song, Y.Y., Guo, K.X., Li, Y.L., Long, S.R., Jiang, P., Cui, J. \& Wang, Z.Q. (2019a). In vitro silencing of a serine protease inhibitor suppresses Trichinella spiralis invasion, development, and fecundity. Parasitology Research 118: 2247-2255. https://doi.org/10.1007/s00436-019-06344-4

Yang, W., Li, L.G., Liu, R.D., Sun, G.G., Liu, C.Y., Zhang, S.B., Jiang, P., Zhang, X., Ren, H.J. \& Wang, Z.Q. (2015). Molecular identification and characterization of Trichinella spiralis proteasome subunit beta type-7. Parasites \& Vectors 8: 18. https://doi.org/10.1186/s13071-014-0626-z

Yang, Y., Bai, X., Li, C., Tong, M., Zhang, P., Cai, W., Liu, X. \& Liu, M. (2019b). Molecular characterization of fructose-1,6bisphosphate aldolase from Trichinella spiralis and its potential in inducing immune protection. Frontiers in Cellular and Infection Microbiology 9: 122. https://doi.org/ 10.3389/fcimb.2019.00122
Yang, Y., Zhang, Z., Yang, J., Chen, X., Cui, S. \& Zhu, X. (2010). Oral vaccination with Ts 87 DNA vaccine delivered by attenuated Salmonella typhimurium elicits a protective immune response against Trichinella spiralis larval challenge. Vaccine 28: 2735-2742. https://doi.org/10.1016/ j.vaccine.2010.01.026

Yue, X., Sun, X.Y., Liu, F., Hu, C.X., Bai, Y., Yang, D.Q., Liu, R.D., Zhang, X., Cui, J. \& Wang, Z.Q. (2020). Molecular characterization of a Trichinella spiralis serine proteinase and its induced protective immunity in a murine model. Veterinary Research 51: 125. https://doi.org/10.1186/s13567020-00847-0

Zhang, S.B., Jiang, P., Wang, Z.Q., Long, S.R., Liu, R.D., Zhang, X., Yang, W., Ren, H.J. \& Cui, J. (2016). DsRNA-mediated silencing of Nudix hydrolase in Trichinella spiralis inhibits the larval invasion and survival in mice. Experimental Parasitology 162: 35-42. https://doi.org/10.1016/j.exppara. 2016.01.005

Zhang, X.Z., Sun, X.Y., Bai, Y., Song, Y.Y., Hu, C.X., Li, X.R., Cui, J. \& Wang, Z.Q. (2020a). Protective immunity in mice vaccinated with a novel elastase-1 significantly decreases Trichinella spiralis fecundity and infection. Veterinary Research 51: 43. https://doi.org/10.1186/s13567-020-00767-z

Zhang, Y., Zeng, J., Song, Y.Y., Long, S.R., Liu, R.D., Jiang, P., Zhang, X., Cui, J. \& Wang, Z.Q. (2020b). Vaccination of mice with a novel trypsin from Trichinella spiralis elicits the immune protection against larval challenge. Vaccines (Basel) 8: E437. https://doi.org/10.3390/vaccines8030437

Zhang, Y.L., Wang, Z.Q., Li, L.G. \& Cui, J. (2013). Molecular characterization of Trichinella spiralis aminopeptidase and its potential as a novel vaccine candidate antigen against trichinellosis in BALB/c mice. Parasites \& Vectors 6: 246. https://doi.org/10.1186/1756-3305-6-246 